\title{
Energy Literacy and Education: The Viewpoint of Stakeholders to Promote Energy Literacy in Education
}

\author{
Rohmatulloh ${ }^{1,2^{*}}$, Aan Hasanah ${ }^{2}$, Muhibbin $\mathrm{Syah}^{2}$, and Nanat Fatah Natsir ${ }^{2}$ \\ ${ }^{1}$ Human Resurces Development Agency for Energy and Mineral Resources, Bandung, Indonesia \\ ${ }^{2}$ Islamic Education, UIN Sunan Gunung Djati, Bandung, Indonesia
}

\begin{abstract}
Energy literacy in education is one strategy to build awareness in students from an early age. The purpose of qualitative research is to capture the views of educational stakeholders on energy literacy programs, especially in Islamic boarding schools. The exploratory case study method uses document study, observation, and semi-structured interviews with school stakeholders, students, parents, the community, and the government representatives. As a result, the energy literacy program in education has become part of the curriculum 2013 at the Islamic boarding school. Energy literacy is a part of environmental education that emphasizes understanding, attitudes, and behaviour changes in science and religious subjects. The teaching aspect in changing understanding does not encounter obstacles. However, habituation and exemplary in forming noble attitudes and behaviours towards the natural use of energy and water are challenging. This success will support government programs and policies in the field of national energy conservation.
\end{abstract}

\section{Introduction}

The topic of energy literacy in Indonesia is one of the national energy conservation policy strategies and programs involving cross-stakeholder to shape energy-saving behaviour (Directorate of Energy Conservation, 2018). The government and society have an essential role in implementing energy literacy programs from an early age. So that they can contribute to reducing the rate of Indonesia's energy demand by $16 \%$ in 2025 and $37 \%$ in 2050, this data is better than the plan without energy conservation interventions (business as usual), which is estimated to reach 238.8 MTOE in 2025, and 682.3 by 2050 [2].

Energy literacy in schools is part of the National Education Curriculum 2013, which emphasizes strengthening character from the primary level (Regulation of the Minister of Education and Culture Number 21 of 2016 concerning Content Standards for Primary and Secondary Education). Energy literacy is the material of environmental education [3]. The global issue of sustainable environmental development is the concern of the government and society because the use of fossil energy is still more than the use of environmentally

*Corresponding author: rohmatulloh@esdm.go.id 
friendly energy sources or new renewable energy (Presidential Regulation Number 27 of 2017 concerning the General Plan for National Energy).

Energy literacy is an effort through education to build awareness for energy users [4]. Hopefully, energy literacy will lead to critical literacy, having the ability and involvement of individuals as citizens [5] in using energy wisely. The concept of energy literacy in primary school children refers to Bloom's taxonomy of educational goals [6], namely cognitive, affective, and behavioural psychology [7]. Education for Sustainable Development Goals (SDGs) develops energy literacy to support the learning goals of Affordable and Clean Energy, which consists of cognitive, socio-emotional, and behavioural or attitudes [8].

Energy literacy has become the concern of researchers in Indonesia. In general, energy literacy research in education still focuses on developing instruments and measuring energy literacy levels, especially for Pre-Service Teachers [9, 10], energy literacy learning in students and by Pre-Service Teachers [11, 12], and measuring the energy literacy of vocational school students [13]. No previous research comprehensively explores the views of education stakeholders in Indonesia involving the views of internal, external, and tertiary stakeholders [14]. There has not been any research conducted at the primary school level. This research is necessary because stakeholders directly or indirectly influence an issue or program as a group or individually [15].

Stakeholders' views in education can improve education management and learning programs in schools [16, 17]. Furthermore, stakeholders involve school owners and managers, teachers, students, parents, government, and society in promoting energy literacy programs in education [14]. Stakeholder analysis is the basis for analyzing various views regarding their roles, interests, and obstacles in conducting their roles to achieve their interests [18], namely the energy literacy program in education.

Stakeholder views can be used as benchmarks to determine the achievement of the energy literacy level [19-22]. Internal school management stakeholders have explored to identify the factors that support and prevent the implementation of energy-saving in schools $[23,24]$, and teachers, as well as parents to find out about energy saving practices in schools and homes $[22,25,26]$.

This previous research can provide positive input to improve energy literacy programs in education following the suggestions of education stakeholders. However, the previous research is still not comprehensive because it only takes some stakeholder views.

In this research, we offer contributions that involve comprehensive stakeholders, namely teachers, school managers, students, parents, government, and the public, to explore their various views regarding energy literacy programs in education. This qualitative research took place at an Islamic boarding school in Bandung Regency, West Java Province. This study can be an input for stakeholders to develop policies and programs and research on energy literacy in Indonesia.

\section{Research Methods}

This study used a qualitative approach to explore stakeholder views on various programs $[17,27]$. This type of research is an exploratory case study to explore a contemporary or current and specific program [28, 29].

The composition and number of participants consisted of internal stakeholders in the three Junior Islamic Boarding Schools (SMPIT Insan Teladan, MTs Ar-Raudloh, MTs. YAPISA), as many as seventeen participants (the head of the foundation, the principal, the head of the Islamic boarding school or pesantren, and the teacher). External stakeholders consisted of eighteen students and two parental representatives. Community stakeholders consisted of one organization representative and five government participants. 
Primary and secondary data collection techniques use three types, namely document study, observation, and interviews. Document studies include policy documents, statistical data reports, school textbooks, previous research, photos of activities, newspaper reports, and other relevant documents (published and unpublished). Observation uses the nonparticipant method, in which the researcher is not actively involved in observing the program at the research location. Semi-structured interviews were conducted face-to-face, telephone, and Whatsapp social media. The selection of participants using a snowball sampling method forms a chain of participants. Interviewing students used group interviews according to the needs and conditions of participants [30]. Data analysis used a reduction procedure from transcribed interview data to obtain patterns or themes of research findings. The thematic analysis results are presented using charts, tables, and text narrative to facilitate the conclusion and the verification process. Verification with participants or member check and triangulation of methods and data sources [31].

\section{Results}

Mapping of education stakeholders related to energy literacy issues or programs in education includes internal and external stakeholders, as shown in (Fig. 1). Internal stakeholders consist of the head of the foundation, the principal, and teachers. External stakeholders consist of parents, students, communities, and the government, who manage the energy and education sectors.

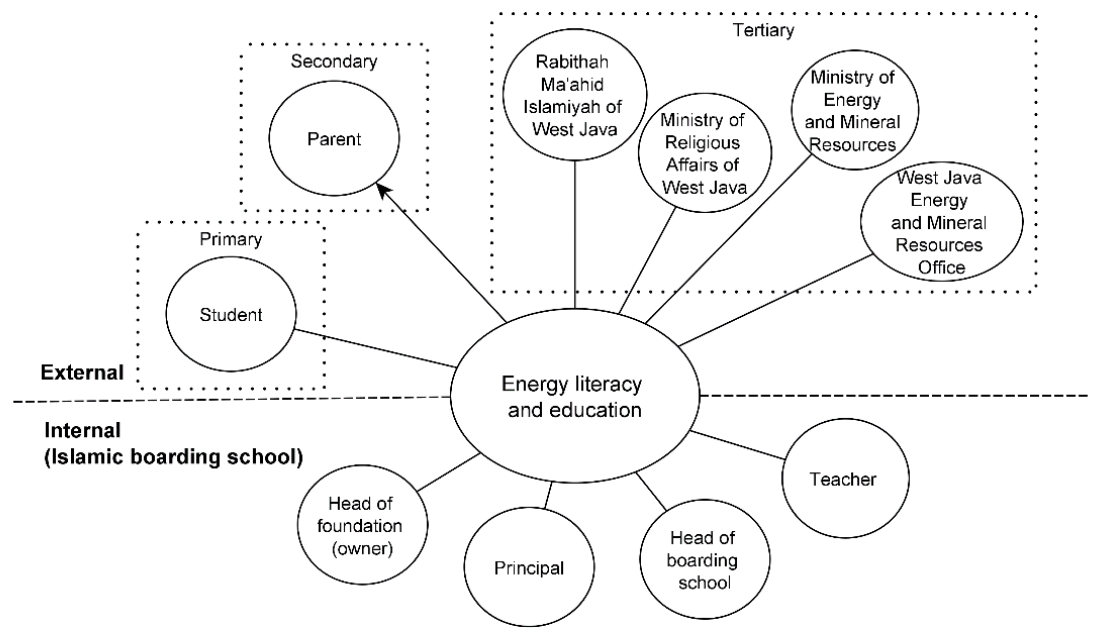

Fig. 1. Map of energy literacy and education stakeholders.

The roles and interests of each stakeholder associated with the energy literacy program in education are shown in Table 1.

Table 1. Roles and interests of stakeholders.

\begin{tabular}{|c|c|c|c|}
\hline No. & Stakeholder & Role & Interest \\
\hline 1 & $\begin{array}{c}\text { Teachers, foundation } \\
\text { managers, and school } \\
\text { managers }\end{array}$ & $\begin{array}{c}\text { Education } \\
\text { provider }\end{array}$ & $\begin{array}{c}\text { Forming noble character on } \\
\text { students }\end{array}$ \\
\hline 2 & Students & $\begin{array}{c}\text { Education } \\
\text { participants }\end{array}$ & \\
\hline 3 & Parents & Primary & \\
\hline
\end{tabular}




\begin{tabular}{|c|c|c|c|}
\hline No. & Stakeholder & Role & Interest \\
\hline & & educator & \\
\hline 4 & Public & $\begin{array}{l}\text { Supporting } \\
\text { government } \\
\text { program } \\
\text { policies }\end{array}$ & $\begin{array}{l}\text { - Increasing children awareness } \\
\text { towards the environment and } \\
\text { energy use } \\
\text { - Increasing Islamic boarding } \\
\text { school as a center to form the } \\
\text { character of virtuous nation }\end{array}$ \\
\hline 5 & Government & $\begin{array}{l}\text { Policy makers } \\
\quad \text { and } \\
\text { implementers }\end{array}$ & $\begin{array}{l}\text { - Increasing public awareness in } \\
\text { using energy } \\
\text { - Increasing the quality of } \\
\text { religious education }\end{array}$ \\
\hline
\end{tabular}

\subsection{Viewpoints of school stakeholders}

Internal stakeholders such as teachers, foundation managers, and school managers have a role in producing graduates with moral dignity. The internalisation of energy-saving character values includes teaching in science and religion subjects, habituation, exemplary, motivating, and enforcing rules, as presented in Table 2.

Table 2. Energy literacy program in Islamic boarding school.

\begin{tabular}{|c|c|c|}
\hline No. & Aspect & Description \\
\hline 1 & Teaching & $\begin{array}{l}\text { - Energy-saving material in science subjects } \\
\text { - Energy-efficient material is connected to religious subjects }\end{array}$ \\
\hline 2 & Habituation & $\begin{array}{l}\text { - Habituation is commonly done in the Islamic boarding } \\
\text { school, although the implementation is not yet optimal } \\
\text { - Habituation is not optimal because the exemplary from } \\
\text { fellow students and teachers are still unprepared }\end{array}$ \\
\hline 3 & Exemplary & $\begin{array}{l}\text { - All the teachers and guardians of students have not done } \\
\text { their exemplary optimally because they do not understand } \\
\text { energy saving. } \\
\text { - Teacher keeps trying to mentor according to the advice of } \\
\text { the principal. } \\
\text { - Exemplary by senior students to juniors as a form of } \\
\text { coaching and role models. However, this effort is still not } \\
\text { optimal because seniors tend to command juniors. }\end{array}$ \\
\hline 4 & Motivating & $\begin{array}{l}\text { - Motivating is conveyed during learning activities and } \\
\text { outside classroom learning such as ceremonies and after the } \\
\text { Duha prayer. } \\
\text { - Motivating in the Islamic boarding school is given after Fajr } \\
\text { and Dhuhr prayers, recitation, performing arts and lecture } \\
\text { exercises, evaluation activities. } \\
\text { - Motivating using the verses of the Qur'an and Hadith, as } \\
\text { well as pearls of wisdom in Islamic boarding schools. }\end{array}$ \\
\hline 5 & $\begin{array}{l}\text { Enforcing } \\
\text { rules }\end{array}$ & $\begin{array}{l}\text { - Effective enforcement of regulations is in the form of } \\
\text { rewards and punishments. } \\
\text { - Enforcement of the rules is more tolerant to avoid human } \\
\text { rights violations. The rules include advising students and } \\
\text { giving sanctions such as cleaning and writing verses from } \\
\text { the Qur'an }\end{array}$ \\
\hline
\end{tabular}


There are no obstacles in implementing literacy programs in schools because they have become part of the subjects in the school curriculum. Students have a good understanding of energy saving. However, this understanding has not been implemented to change attitudes and behaviour. Likewise, teachers have not maximally provided exemplary and habituation because knowledge about energy saving is limited. The following is an interview with the principal.

Habitation and exemplary have many obstacles. There is no specific program on energy saving. Hopefully, there will be progress in input for children and teachers with energysaving and environmental characteristics. So, understanding increases into habituation. (PGA-02).

\subsection{Viewpoints of students and parents stakeholders}

Students are the primary input component in the education system that experience transformation to become graduates with noble character. Students already understand about environmentally friendly energy sources or from new and renewable energies. In everyday life, students can distinguish which activities are wasteful or energy efficient. The following is an interview with a group of students who are ironing school uniforms and having dinner.

Researcher: what energy do you know?

Students: electricity, wind. Already studied in science

Researcher: what electrical equipment do you usually use?

Students: iron, light, television. Mobile is not allowed. After finished using it, we immediately turned it off.

Researcher: what is the meaning of saving or wasteful of energy? for example?

Students: not turned it off. We forgot to turn off the electrical equipment and the teacher scolded us. We are not being punished. Usually, the teacher commands us to wash dishes according to the set schedule. (PPA-01)

Interviews with other groups of students, namely as follows:

Researcher: What is energy?

Students: Sun, wind, water, air, electricity. The street lights use the sun. Tools need energy such as irons, motorbikes, cars, lights, water.

Researcher: what is the meaning of saving or wasteful of energy? Can you give an example?

Students: saving is turning off the lights during the day, ironing clothes a lot, using enough water, not washing clothes excessively. Cars need a lot of fuel. It's best to go to a nearby location on foot or by bicycle to save gas. If the room is no longer in use, then turn off the lights. (Researchers show wasteful and energy-efficient images using a tablet PC, and students pinpoint the energy-efficient and wasteful ones. Some are indifferent, and some are extravagant). Usually, we often forget to turn off the lights during the day. Ironing in the hall together. We forgot to turn off the water until dawn.

Researcher: what are the sources of energy?

Students: the energy from animals buried for years becomes gasoline, diesel, gas. Living animals become energy from excrement to gas. Energy from gas, geothermal. Energy subjects since grade VII-IX, the teacher's name is Mrs. Lela. (PPY-01)

Increasing understanding about energy-saving and the environment has not changed students' attitudes and behaviour in using energy at school and home. For the millennial generation, technology is very familiar to them. They are familiar with the latest electronic technology tools, which use a lot of energy, especially electricity. Based on the views of 
parents, they often provide continuous advice to children on the use of electronics, electricity, and water. The following is an interview with parents:

Parents often remind them, for example, to turn off the lights during the day and not watch television until late at night. Parents always pay attention, remind, and give warnings. Parents provide an example by rarely watching television, turning off television only, and unplugging the cable. (POA-02)

Exemplary is also an important thing for parents to do with their children. However, sometimes parents do not fully provide an example because parents are still used to using electronic and electrical equipment waste.

\subsection{Viewpoints of government and public stakeholders}

Central government stakeholders, as managers of the energy sector, must increase public awareness of energy use. The problems encountered in energy conservation are low energy awareness, limited knowledge, and an understanding of the importance of energy in life [32]. This effort is expected to contribute to reducing national energy demands [2]. Meanwhile, the Department of Energy and Mineral Resources of West Java Province is a provincial government that must increase the availability and utilization of new and renewable energy sources based on local potential and increase energy savings [33]. The importance of building energy-saving behaviour is because West Java has become one of the provinces with the highest number of electricity customers (housing segment) in Indonesia, amounting to 12.4 million, and the level of electricity consumption for all segments of $17.6 \mathrm{GWh}$ in 2017 [34]. This data corresponds to the West Java population of 48.7 million in 2018 or $19 \%$ of Indonesia's population in 2018, 255 million. [35].

Not many people know about energy conservation policies in Indonesia, even though this policy has existed since 1982 (Presidential Instruction No. 9 of 1982 concerning Energy Conservation). Energy conservation policies are also related to environmental policies and implementation of energy literacy in schools as part of the Adiwiyata Program or schools with environmental cultures (Regulation of the Minister of Environment Number 5 of 2013 concerning Guidelines for the Implementation of the Adiwiyata Program).

Socialization activities and energy-saving competitions have been held in schools since 2017 to increase public awareness of using energy wisely in twelve provinces. Each province involves 30-101 schools; the socialization took place at boarding school educational institutions, formal schools, Islamic student organizations such as Nahdlatul Ulama, and the Scout movement (Pramuka). Another activity is preparing Energy Saving books for elementary school children (grades 1-3 and 4-6) and Junior High school (grades 7-9), and Marine Energy Study Book for Junior High School (grades 7-9). The energy conservation program by the West Java Provincial Government includes promoting and educating energy conservation and saving programs and making promotional and broadcast media in the energy sector. Educational programs in schools focus on introducing local renewable energy sources. This program aims to encourage students' awareness that West Java has the potential for new and renewable energy, such as micro-hydro, solar, wind, cattle waste, and organic waste/garbage [36]. This strategic issue is followed up with a thematic outreach program for high school students adjusted to the local energy potential in the school area.

The government stakeholder, the Ministry of Religion of West Java Province, manages the formal Islamic education sector. Religious education is an influential pillar of national education development to realize quality human resources and noble character (Government Regulation Number 55 of 2007 concerning Religious Education and Religious Education) as an implementation of Law Number 20 of 2003 concerning the National Education System. 
The Ministry of Religion of West Java Office improves the quality of religious education in Islamic boarding schools by supporting improving health quality and the development of superior and vocational Islamic boarding schools [37]. Special programs for energy-saving and loving the environment are not yet a priority. However, teaching energy saving in Islamic boarding schools is an important activity to be conveyed to students from an early age.

Based on the West Java Islamic boarding school association (Rabithah Ma'ahid Islamiyah), teaching energy-saving characters in boarding schools is not explicitly done. Islamic boarding schools are generally already beautiful and have lots of plants. Loving the environment is a common practice in Islamic boarding schools because students carry out their activities independently. However, there are still weaknesses in some boarding schools, namely, the environment inside the boarding school itself is poorly maintained. Efforts to teach energy-saving values in boarding schools remain valuable because they have various benefits. As a practical benefit, it reduces the cost of electricity for Islamic boarding schools.

\section{Discussion}

Efforts to promote energy literacy programs in education, especially in Islamic boarding schools, have been well implemented because they are part of the curriculum 2013. This program involves teaching character values comprehensively and programmatically by doing habituation, exemplary, motivating, and enforcing [38-40]. However, in its implementation, there are still obstacles, such as problems of habituation and exemplary. Energy-saving character values refer to religious and scientific values. This value is a characteristic of education in Indonesia, where religion has a role in everyday life and education. The Pew Research Center confirms the substantial function of religion in Indonesia in its society [41], including environmental education, which emphasizes religious attitudes [42].

The energy literacy program in Indonesian education is better known as environmental education. In Japan, energy literacy in the education curriculum is not specifically in energy education but environmental education. Energy topics are set in science, social, technology, and economics subjects [43]. On the other hand, the United States has applied energy literacy to build energy awareness in its curriculum since the energy crisis of the 1970s, namely energy education with energy literacy as its pillar $[4,7,44]$. However, environmental education and energy literacy cannot be separated from two other themes, namely environmental change and energy literacy [45].

Energy literacy programs for students or the post-millennial generation $\mathrm{Z}$ and Alpha are very crucial. This generation is modest in using electrical and electronic devices at home such as lights, televisions, computers, laptops, and internet connections. Children also get permission from their parents to support learning activities or entertainment, which has been used for a long time. [46-48].

This generation is called the Thumbelina generation. Thumbelina is a child who lives during the digital revolution, so she is familiar with digital media or technology to support learning and her various life activities with just one finger [49]. Of course, this generation must receive guidance to make electronic device usage balanced with energy-saving behaviour. In previous studies, children were not used to turning off electronic devices after using them, even though they had a positive attitude towards energy saving. [22].

The energy literacy program is assumed to have a more comprehensive impact on its application in society to support government programs. This is an expected contribution to national and local energy consumption, as well as environmental enhancement. Environmental damage must be reduced by energy-saving behaviour and looking for 
alternative energy sources that are environmentally friendly or emit less carbon dioxide (CO2) combustion gases. $\mathrm{CO} 2$ gas emissions from burning fossil fuels can increase Greenhouse Gases (GHG) levels in the atmosphere. It can also increase the intensity of the Greenhouse Effect (ERK) that causes global warming. [50].

The issue of environmental management encourages the continued development of environmental education called Education for Sustainable Development Goals. This term has emerged since the Earth Conference in Rio in 1992. Development does not only achieve the welfare of today's society but also for future generations. Environmental education covers energy and water issues from the cognitive, socio-emotional, and behavioural realms $[3,8,51]$. If it goes well, another benefit is that the cost of using electricity and water energy decreases, and the school accreditation score increases [52].

\section{Conclusion}

In general, stakeholders' views in promoting energy literacy in education have the same goal, namely to encourage students to use energy and water reasonably. Learning is carried out at school and home using various methods of cultivating energy-saving character values. The problem of habituation and exemplary from teachers, parents, and fellow students is quite challenging. The reason is the limited understanding of teachers and parents and environmental factors among students. However, if it is running well, energy literacy is expected to support government and community programs in national energy conservation.

The acknowledgements: The researcher would like to express his gratitude to the research participants, who came from various stakeholders involved in the energy literacy program in education. They all help by providing data and linking networks, broadening the relationship between researchers and diverse stakeholders.

\section{References}

1. Directorate of Energy Conservation, Data dan informasi konservasi energi 2018, Ditjen EBTKE Jakarta, (2018)

2. National Energy Board, Outlook energi Indonesia 2016, Dewan Energi Nasional Jakarta, (2016)

3. J. A. Palmer, Environmental education in the 21st Century: Theory, practice, progress and promise, (Routledge London, 1998)

4. U.S. Department of Energy, Energy literacy: Essential principles and fundamental concepts for energy education, U.S. Department of Energy Washington, (2012)

5. J. W. Collins, N. P. O'Brien, The greenwood dictionary of education, (Greenwood Press London, 2003)

6. L. W. Anderson, D. R. Krathwohl, P. W. Airasian, K. A. Cruikshank, R. E. Mayer, P. R. Pintrich, J. Raths, M. C. Wittrock, A taxonomy for learning, teaching, and assesing: A revision of bloom's taxonomy of educational objectives, (Addison Wesley Longman New York, 2001)

7. J. DeWaters, S. Powers, J. Environ. Educ., 44, 38 (2013)

8. UNESCO, Education for sustainable development goals learning objectives, UNESCO Paris, (2017) 
9. M. Yusup, A. Setiawan, N. Y. Rustaman, I. Kaniawati, in J. Phys. Conf. Ser., (2017)

10. S. Sukendar, A. Setiawan, J. Sci. Educ. Res., 2, 25 (2018)

11. N. Ilmi, L. A. Sanjaya, A. S. Budi, I. M. Astra, R. W. Puspa, F. A. Dinata, R. A. Putri, H. B. Winarko, W. A. Pertiwi, D. P. Rasmi, AIP Conf. Proc., 2320, (2021)

12. P. D. A. Putra, Y. Kumano, New Educ. Rev., 53, 153 (2018)

13. I. Mustain, Y. Herlina, Sci. Educ., 8, 131 (2019)

14. E. Sallis, Total quality management in education, (Kogan Page Ltd, London, 2002)

15. UNDP, Handbook on planning, monitoring and evaluating for development results, United Nations Development Programme New York, (2009)

16. A. Bandur, Int. J. Educ. Manag., 32, 1082 (2018)

17. N. F. Sa Don, R. A. Alias, and N. Ohshima, ARPN J. Eng. Appl. Sci., 10, 18104 (2015)

18. J. M. Bryson, Public Manag. Rev., 6, 21 (2004)

19. E. Ç. Altuntaş, S. L. Turan, Renew. Energy, 116, 741 (2018)

20. N. Zografakis, A. N. Menegaki, K. P. Tsagarakis, Energy Policy, 36, 3226 (2008)

21. L. Lee, Y. Lee, J. W. Altschuld, Y. Pan, Energy Policy, 76, 98 (2015)

22. I. Aguirre-Bielschowsky, R. Lawson, J. Stephenson, S. Todd, Environ. Educ. Res., 23, $832(2017)$

23. B. Castleberry, T. Gliedt, J. S. Greene, Energy Policy, 88, 216 (2016)

24. W. Kiatruangkrai, E. Leelarasmee, Int. J. Energy Econ. Policy, 6, 513 (2016)

25. M. J. Fell, L. F. Chiu, Energy Policy, 65, 351 (2014)

26. M.-C. Chen, C.-C. Chou, C.-T. Hsiung, J. Ilmu Pendidik. Fis., 5, 115 (2020)

27. E. McInnes, S. Middleton, G. Gardner, M. Haines, M. Haertsch, C. L. Paul, P. Castaldi, BMC Health Serv. Res., 12, 1 (2012)

28. J. W. Creswell, Qualitative inquiry and research design, choosing among five approaches, (SAGE Publications Thousand Oaks, 2007)

29. R. Yin, Case study research: Design and methods, (SAGE Publications Thousand Oaks, 2003)

30. A. Lewis, Br. Educ. Res. J., 18, 413 (1992)

31. M. B. Miles, A. M. Huberman, Qualitative data analysis: An expanded sourcebook, (SAGE Publications Thousand Oaks, 1994)

32. Directorate General of New and Renewable Energy and Enegy Conservation, Rencana strategis ditjen EBTKE 2015-2019, Ditjen EBTKE Jakarta, (2015)

33. West Java Energy and Mineral Resources Office, LKIP dinas ESDM Provinsi Jawa Barat 2018, Dinas ESDM Provinsi Jawa Barat, Bandung, (2019)

34. Directorate General of Electricity, Statistik ketenagalistrikan 2017, Ditjen 
Ketenagalistrikan Jakarta, (2018)

35. Statistics Infonesia of West Java, Kompilasi indikator statistik terkini Jawa Barat 2019, BPS Provinsi Jawa Barat, Bandung, (2019)

36. West Java Energy and Mineral Resources Office, Renstra dinas ESDM Provinsi Jawa Barat 2013-2018, Dinas ESDM Provinsi Jawa Barat, Bandung, (2013)

37. Ministry of Religious Affair of West Java, Rencana strategis kanwil kementerian agama Provinsi Jawa Barat 2015-2019, Kemenag Provinsi Jawa Barat, Bandung, (2015)

38. A. Hasanah, Pendidikan karakter berbasis islam (Studi atas konsep dan kontribusinya dalam pembentukan karakter bangsa), Program Pascasarjana UIN Sunan Gunung Djati, (2011)

39. Ministry of National Education, Desain induk pendidikan karakter, Kemdiknas Jakarta, (2010)

40. T. Lickona, Action Teach. Educ., 20, 77 (1999)

41. Pew Research Center, A changing world: Global views on diversity, gender equality, family life and the importance of religion, (Pew Research Center Washinghton, 2019)

42. L. Parker, Environ. Educ. Res., 23, 1249 (2016)

43. Y. Akitsu, A study of energy literacy among lower secondary school students in Japan, Kyoto University, (2018)

44. J. T. Morrisey, L. Barrow, Sci. Educ., 68, 365 (1984)

45. S. N. Jorgenson, J. C. Stephens, B. White, J. Environ. Educ., 50, 160 (2019)

46. UNICEF, The State of world's children 2017: Children in a digital world, United Nations Children's Fund, New York, (2017)

47. Hendriyani, E. Hollander, L. D’Haenens, J. W. J. Beentjes, Asian J. Commun., 22, 304 (2012)

48. N. Mirchandani, P. Mulles, Mobile device usage among young kids: A Southeast Asia Study, The Asian Parent Insight Singapura, (2014)

49. M. Serres, Thumbelina: The Culture and technology of millennials, (Rowman \& Littlefield International London, 2015)

50. O. Soemarwoto, Ekologi, lingkungan hidup dan pembangunan, (Djambatan Jakarta, 2004)

51. S. Hamzah, Pendidikan lingkungan: Sekelumit wawasan pengantar, (Refika Aditama Bandung, 2013)

52. Ministry of Education and Culture, Indikator mutu dalam penjaminan mutu pendidikan dasar dan menengah, Kemdikbud Jakarta, (2017) 